\title{
What Determines Firm's Innovation? The Case of Catching-up CEE Countries
}

\author{
DOI: 10.12776/QIP.V25I1.1513 \\ Michael Vávra, Gregor Vohralík, Viktor Prokop, Jan Stejskal
}

Received: 2020-10-15 Accepted: 2021-03-16 Published: 2021-03-31

\begin{abstract}
Purpose: The purpose of the paper is to recognize significant innovation determinants on firms' product, process, and overall innovation activity.

Methodology/Approach: The source of data for the analysis is the Community Innovation Survey 2012-2014. If the company has implemented the relevant innovation activity, they acquire a value of 1 , or, if the company has not performed a certain activity in the period, they reached 0 . As the variables are binary, the logistic regression analysis was used.

Findings: Based on the results from the analysis, we defined the proper determinants of firms' innovation activities but unfortunately, firms are not able to achieve innovative outputs, specifically within CEE countries. This is due, among other things, to several factors such as different conditions in individual countries, different innovation policies at the national as well as company level, managerial approach (aversion) to risk, mistrust between the various actors, and many others. A typical example is the impact of internal R\&D on firm innovations. While in the case of product innovations we found a significant positive impact, in the case of process innovations the impact was negative
\end{abstract}

Research Limitation/Implication: We performed on outdated data and we did not make a comparison with countries from Western Europe.

Originality/Value of paper: The paper analyses innovation determinants and it is importance for innovation activities within the CEE countries.

Category: Research paper

Keywords: product innovation; process innovation; CEE countries; knowledge 


\section{INTRODUCTION}

Knowledge and innovation have been recently determined as a strategic resource of competitive advantage in today's global and intensive business environment (Nielsen, 2010; Mahdi, Nassar and Almsafir, 2019). Moreover, firms realized that acquiring external knowledge, as a vital factor of economic growth, is an efficient way to ensure the achievement of their goals (Che et al., 2019; Asimakopoulos, Revilla and Slavova, 2020). Subsequently, it helps to gain a sustainable competitive advantage in the marketplace (Barkhordari, Fattahi and Azimi, 2019). Therefore, we can see a shift from closed to open innovation models that provide firms a number of various resources and other advantages connected with the firm's openness. However, there are significant differences between firms and countries and their readiness to become more open. While a number of Western European countries successfully applied various models based on Chesbrough's open innovation concept (see e.g. Chesbrough, 2017; Bogers, Chesbrough and Moedas, 2018), Central and Eastern European (CEE) countries struggled. There are several reasons for this phenomenon.

On the one hand, Western countries (e.g. Germany) belong to the group of countries that are able to develop their innovation potential, reach high positions in the inter-European firm comparison due to their innovation performance, and represent the global leaders in competitiveness, not only in the context of the knowledge economy (Prokop and Stejskal, 2019a). On the other hand, despite the fact that the communist regime in CEE countries collapsed, the firm's and its employees' mindset within CEE countries might still be affected by the ideologies and cultural specifics from the past (Ivanova-Gongne et al., 2018). In terms of scientific publication counts in the Web of Science, post-communist countries are still lagging far behind their EU counterparts (Jurajda et al., 2017). Moreover, firms within these catching-up CEE countries are affected by several negative effects, such as lock-in or not-invented-here (NIH). The dependence of the lock-in effect is among the concepts that seek to explain the decline of the region's economic development how highly productive regions could lose competitiveness (MacVaugh and Schiavone, 2010). On the other hand, notinvented-here syndrome describes as an employee's generally has difficulties with externally introduced ideas and developments and are not able or they are not willing to accept external knowledge sources (Kathoefer and Leker, 2012).

Therefore, there are number of studies that focused on the CEE countries. For example, Stejskal, Mikušová Meričková and Prokop (2016) analyzed the case of cooperation within the Czech Republic in the process of product and process innovations creation. They showed that cooperation with universities and research institutes plays an important role. Odei, Stejskal and Prokop (2020) found out, in the case of countries from Visegrad Group (except Poland), that engaging in R\&D was probable to improve product innovations by $48 \%$, process, and organizational innovations by $27 \%$, and market innovations by $22 \%$. The study also shows that public subsidies for innovations from local, central, and EU sources significantly influenced firm-level innovations. Lastly, innovations in 
these countries were also significantly and positively stimulated by certain firm characteristics such as size and ownership. Žítek and Klímová (2016) explored the ways how is knowledge involved in innovation processes and how knowledge flow within and between organizations in the Czech Republic. Kotkova Stríteská and Prokop (2020), in the case of 10 European countries, identified sustainable sources of competitive advantage that represent a way to achieve business goals. They proved that for innovative leaders, key innovation determinants (in-house R\&D; market-related activities, including market research and launch advertising; design of goods or services) have a positive impact on produced innovations while for the innovation followers, the same group of innovation determinants has a negative influence.

However, possible disadvantage of the above-mentioned studies is the fact that they have primarily focused on selected countries and industries and made comparisons of them. These results are subsequently more difficult to apply in public policy-making across other countries. Moreover, practical recommendations based on the results of these studies may not accurately capture firms' needs in other sectors. For these reasons, we see an opportunity to build on these limitations of previous research. Therefore, the main motivation of our article is to verify the applicability of the results obtained for each country to a larger sample of countries and to provide relevant results that will be applicable across countries and industries, by using a random selection of firms across CEE industries to create aggregated data set. For the purpose of this study, we are using the same data sets as some of the previous studies provided by Eurostat these are the data from the latest available Community Innovation Survey.

The rest of the paper is structured as follows. The next section covers the theoretical background. Third part provides the research methodology and the characteristics of the dataset. Subsequently, we show the research results. Following these parts, discussion and concluding remarks are included.

\section{THEORETICAL BACKGROUND}

Knowledge is nowadays seen as one of the key drivers of economic growth and represent conditions for successful innovation, patents, and the development of new technologies (Tchamyou, 2017; Asim and Sorooshian, 2019). Several authors (e.g. Nonaka and Takeuchi, 1995; Chergui, Zidat and Marir, 2018; Vasin et al., 2020) divide knowledge according to their nature into explicit and tacit. Explicit knowledge is open and could be easily interpreted and can be systematically categorized. It can be easily expressed and communicated using language, writing, illustration, mathematical formula, or digital recording in the form of written documents, such as reports or manuals (Hau et al., 2013). These knowledges can be stored in software as an information system in the form of data or hardware (Barcelo-Valenzuela et al., 2016). On the other hand, tacit knowledge is hidden knowledge in people's minds. These knowledges are not easily codified or articulated because are embedded in an individual's brain or 
experiences, such as know-how or skills (Goffin and Koners, 2011). Moreover, tacit knowledge is highly personal and difficult to be transferred to another person by written word or verbal expression (Battistutti and Bork, 2017).

The knowledge economy as well as knowledge-based economy represent wellknown theoretical concepts that work with knowledge. Mokyr (2002) defines the knowledge economy as a result of technological and scientific progress of the last two centuries and states that knowledge are significant element of economic and social growth. This growth helped to discover new technologies and new ways how to access knowledge through networks' creation with universities, research institutions, firms, and other partners. The knowledge economy is defined as a transformed economy that transfers investment into assets based on knowledge (research and development, design, software, human and organizational potential) and investment in physical assets (machinery, equipment, buildings, cars) and makes use of knowledge as the principal engine of economic prosperity (Brinkley, 2006; Tchamyou, 2017). According to Li, Tarafdar and Rao (2012), it is an important determinant of firm growth, survival, and economic performance. On the other hand, a knowledge-based economy is directly rooted in the production, distribution, and use of knowledge and information through the process of economic learning to catalyze and accelerate the sustainability of economic growth (Momeni, Elahi and Najafi, 2017; Minárik, Vokoun and Stellner, 2018). In the knowledge-based economy innovation systems, firms, organizations, and the government interact with one another and become actors in the cycles of knowledge conversion and innovation (Park, 2001). Moreover, knowledge-based view points out the role of knowledge as the main source for creation of strategic opportunities (Juknevičiené, 2017).

In the recent year, there were a huge debate on the sources of innovation and the role of open and closed innovation approaches. The closed innovation comes from the company's environment, which takes place within the company, uses internal recourses like know-how, technology, processes, etc. (Chesbrough, 2003; Manzini, Lazzarotti and Pellegrini, 2017). Otherwise open innovation concept is connected with the use of external knowledge sources. In addition, while innovations are not exclusively in the private sector domain separated from the public sector (Lavčák, Hudec and Sinčáková, 2019), innovation could be generated in co-operation/collaboration with various partners such as universities, research organizations, regional customers and/or suppliers, venture capitalists, and industry/cluster associations or business assistance centers (Ili, Albers and Miller, 2010; Dries et al., 2014). In this study, therefore, we build on the assumptions of open innovation theory.

Moreover, in the contexts of the knowledge and knowledge-based economy, as well as in the era of the growing importance of open innovation, there were a huge debate on the ways how to express and measure innovations and its determinants. On the one hand, authors dealt with an interesting question on how to express innovation as dependent (output) variable within analyses focused on the measuring of firm productivity and innovation performance (Carayannis and 
Grigoroudis, 2014). According to Dziallas and Blind (2019) and Prokop and Stejskal (2019b), innovation could be measured by the number of patents, R\&D budget, the number of new product ideas, and the percentage of ideas with commercialization potential. Otherwise, Janger et al. (2017) measured innovation output e.g. as the share of firms that have introduced innovations. On the other hand, while the level of innovation activities is influenced by several factors (independent variables), scholars focused on the factors that determine the level of innovation in a given company, state, or region. These are, for example, the size of companies (Zona, Zattoni and Minichilli, 2013), the innovation capacity of companies (Rohrbeck and Gemünden, 2011; Forsman 2011), risk aversion (Arundel, 2017), market situation (Liu and Atuahene-Gima, 2018), innovation environment (Wang et al. 2016; Lukovics et al., 2017), the volume of available knowledge (Sun, Liu and Di, 2020; Bacon, Williams and Davies, 2020), and many others.

Similarly, there were number of studies that focused on firms' innovation and its determinants within CEE countries in recent years. For example, in the case of Estonian and Lithuanian manufacturing firms, Prokop, Stejskal and Hajek (2018) showed that in Estonia, innovation activities are influenced by the following determinants: internal $\mathrm{R} \& \mathrm{D}$ expenditures, public funding from the government, cooperation with companies within the firm group, cooperation with customers, the establishment of subsidiaries outside Europe, and participation in a group of companies. On the other hand, in Lithuania, innovation activities are influenced by the following factors: public funding from the government, cooperation with companies within the firm group, the introduction of a new or improved process on the market, and the introduction of a new or improved product on the market. Hudec (2015) analyzed the innovation efficiency of the Visegrad Group (the Czech Republic, Hungary, Poland, and Slovakia) as well as their regions by considering R\&D expenditures as inputs and patents as outputs. He observed that Visegrad countries do not belong to the best performers in innovation and competitiveness in the EU.

Moreover, Kraftova and Kraft (2018) examined relationships between economic performance and the pro-innovation factors which represent the intensity of R\&D at the level of the national economy of the EU Member States. They found out that the most important influence on economic growth is the support of R\&D by entrepreneurial subjects, followed by the degree of allocation of funds to higher education. Their research also shown that there is probably a certain degree of saturation for an increase in expenditures of $R \& D$ is associated with lower performance gains. Chlebovsky, Schüller and Škapa (2018) analysed how Czech firms, oriented on product innovations, are prepared in terms of their internal infrastructure for effective customized product solution development and delivery to their customers, in comparison with Austrian, German and Swiss firms.

Following above-mentioned studies on this topic, we build on the previous findings and to propose novel way of measuring firms' innovation performance 
and its determinants in CEE countries, using a random selection of companies across countries. Moreover, we aim to analyze the influence of innovation determinants on firms' product, process, and overall innovation activity.

\section{METHODOLOGY}

The source of data for the analysis is the Community Innovation Survey 2012 2014 conducted by Eurostat. The Community Innovation Survey (CIS) is a harmonized survey and also a part of the EU's scientific and technological statistics, carried out every two years in the EU Member States. CIS is often used to analyze the innovation activities of companies. It contains 2,363 companies from the Czech Republic (CR), 510 companies from the Slovak Republic (SR), 472 companies from Estonia (EE), and 1,125 companies from Lithuania (LT). The companies represented various sectors of the economy. Note, this is the latest available version of CIS.

CIS questionnaire provides several information about firms' innovation activities. In this study, we used combinations of different innovation activities that are shown in Table 1. If the company has implemented the relevant innovation activity, they acquire a value of 1 , or, if the company has not performed a certain activity in the period, they reached 0 .

Table 1 - CIS Data On Innovation Activities

\begin{tabular}{|l|l|}
\hline Variable (abbrev.) & \multicolumn{1}{|c|}{ Description } \\
\hline INPDGD & $\begin{array}{l}\text { Introduction of new or significantly improved goods on the market in } \\
\text { the period 2012-2014. }\end{array}$ \\
\hline INPDSV & $\begin{array}{l}\text { Introduction of a new or significantly improved service on the market in } \\
\text { the period 2012-2014. }\end{array}$ \\
\hline INPSPD & $\begin{array}{l}\text { Introduction of a new or significantly improved method of production of } \\
\text { goods or services in the period 2012-2014. }\end{array}$ \\
\hline INPSLG & $\begin{array}{l}\text { Introduction of a new or significantly improved method of logistics, } \\
\text { method of delivery or distribution of inputs, goods or services in the } \\
\text { period 2012-2014. }\end{array}$ \\
\hline INPSSU & $\begin{array}{l}\text { Introduction of new or significantly improved support activities for the } \\
\text { main processes, such as maintenance systems or operations for } \\
\text { purchasing, accounting, or computer technology in the period 2012- } \\
\text { 2014. }\end{array}$ \\
\hline
\end{tabular}

Notes: INPDGD - product innovation, INPDSV - service innovation, INPSPD - innovation of method of production of goods or services, INPSLG - innovation of methods of logistics, delivery or distribution of inputs, goods or services, INPSSU - innovation of support activities. 
Based on the available data on firms' innovation, we created models for overall, product and process innovations as follows:

- Overall innovation activities - if the company performed at least one of the activities INPDGD, INPDSV, INPSPD, INPSLG, INPSSU then the output quantity of the model is equal to 1 . If the company did not perform any of the activities, then the value of the output quantity is equal to 0 ;

- Product innovation activities model - if the company has performed at least one of the INPDGD, INPDSV activities, then the output value of the model is equal to 1 ; if the company has not performed any of the activities, then the value of the output quantity is equal to 0 ;

- Process innovation activities model - if the company has performed at least one of the activities INPSPD, INPSLG, INPSSU then the output quantity of the model is equal to 1 ; if the company has not performed any of the activities, then the value of the output quantity is equal to 0 .

Input (independent) variables are listed in Table 2. The selection of independent variables is based on the previous part of the paper, where they are identified based on a search of the literature. These variables are selected from the data available in the CIS survey.

Table 2 - List of Independent Variables

\begin{tabular}{|c|c|}
\hline Independent variable & Description of an independent variable \\
\hline $\begin{array}{l}\text { Participation in the firm } \\
\text { group } \\
\text { GP }\end{array}$ & $\begin{array}{l}\text { The company is part of a group. A group consists of two or more legally } \\
\text { defined jointly owned enterprises. Each company in the group can serve } \\
\text { a different geographic and product market. }\end{array}$ \\
\hline $\begin{array}{l}\text { Sales on the local market } \\
\text { MARLOC }\end{array}$ & $\begin{array}{l}\text { In the period 2012-2014, the company sold its products/services to the } \\
\text { local and regional market. }\end{array}$ \\
\hline $\begin{array}{l}\text { Sales on the national market } \\
\text { MARNAT }\end{array}$ & $\begin{array}{l}\text { In the period } 2012-2014 \text {, the company sold its products/services on the } \\
\text { national market (in their country). }\end{array}$ \\
\hline $\begin{array}{l}\text { Sales on the EU market } \\
\text { MAREUR }\end{array}$ & $\begin{array}{l}\text { In the period 2012-2014, the company sold its products/services on the } \\
\text { EU market. }\end{array}$ \\
\hline $\begin{array}{l}\text { Sales to other countries } \\
\text { MAROTH }\end{array}$ & $\begin{array}{l}\text { In the period 2012-2014, the company sold its products/services to other } \\
\text { countries than are listed for MAREUR. }\end{array}$ \\
\hline $\begin{array}{l}\text { Internal research and } \\
\text { development } \\
\text { RRDIN }\end{array}$ & $\begin{array}{l}\text { Research and development activities performed internally to generate } \\
\text { new knowledge or solve scientific or technical problems (including own } \\
\text { software development that meets this requirement). }\end{array}$ \\
\hline $\begin{array}{l}\text { External research and } \\
\text { development } \\
\text { RRDEX }\end{array}$ & $\begin{array}{l}\text { The company has outsourced research and development to other } \\
\text { companies or to public or private research organizations. }\end{array}$ \\
\hline $\begin{array}{l}\text { Acquisition of machinery, } \\
\text { equipment, software and } \\
\text { buildings } \\
\text { RMAC }\end{array}$ & $\begin{array}{l}\text { Acquisition of advanced machinery, equipment, software and buildings } \\
\text { to be used for the production and introduction of new or significantly } \\
\text { improved products or processes. }\end{array}$ \\
\hline
\end{tabular}




\begin{tabular}{|l|l|}
\hline Independent variable & \multicolumn{1}{|c|}{ Description of an independent variable } \\
\hline $\begin{array}{l}\text { Obtaining existing knowledge } \\
\text { from other companies or } \\
\text { organizations } \\
\text { ROEK }\end{array}$ & $\begin{array}{l}\text { Acquisition of existing know-how, copyrighted works, patented and } \\
\text { non-patented inventions, etc. from other enterprises or organizations for } \\
\text { the development of new or significantly improved products and } \\
\text { processes. }\end{array}$ \\
\hline $\begin{array}{l}\text { Training, training for } \\
\text { innovative activities } \\
\text { RTR }\end{array}$ & $\begin{array}{l}\text { In-house or contracted out training for your personnel specifically for } \\
\text { the development and/or introduction of new or significantly improved } \\
\text { products and processes. }\end{array}$ \\
\hline $\begin{array}{l}\text { Market introduction of } \\
\text { innovations } \\
\text { RMAR }\end{array}$ & $\begin{array}{l}\text { In-house or contracted out activities for the market introduction of your } \\
\text { new or significantly improved goods or services, including market } \\
\text { research and launch advertising. }\end{array}$ \\
\hline $\begin{array}{l}\text { Design } \\
\text { RDSG }\end{array}$ & $\begin{array}{l}\text { In-house or contracted out activities to alter the shape, appearance or } \\
\text { usability of goods or services. }\end{array}$ \\
\hline $\begin{array}{l}\text { Public financial support for } \\
\text { local and regional institutions } \\
\text { FUNLOC }\end{array}$ & $\begin{array}{l}\text { Public financial support for innovative activities from local and regional } \\
\text { institutions (regions, municipalities). }\end{array}$ \\
\hline $\begin{array}{l}\text { Public financial support from } \\
\text { the government } \\
\text { FUNGMT }\end{array}$ & $\begin{array}{l}\text { Public financial support for innovation activities from the government } \\
\text { (including government agencies or ministries). It includes financial } \\
\text { support through tax rebates or deductions, grants, subsidized loans and } \\
\text { loan guarantees. }\end{array}$ \\
\hline $\begin{array}{l}\text { Public financial support from } \\
\text { FUNEU }\end{array}$ & $\begin{array}{l}\text { Public financial support for innovation activities from the EU. It } \\
\text { includes financial support through tax rebates or deductions, grants, } \\
\text { subsidized loans and loan guarantees. }\end{array}$ \\
\hline
\end{tabular}

The methodological process consists from two crucial steps. First, similarly to previous above-mentioned studies focused on the case of CEE countries, we tested influence of selected determinants on firms' overall, product and process innovation outputs. Second, 400 companies across countries were randomly selected to verify the applicability of the results obtained for each country to a larger sample of countries.

As the variables are binary, the logistic regression analysis is used. The relationship between innovation (INN) output and its determinants (shown and specified in Table 4) could be defined as follows (Divisekera and Nguyen, 2018; Prokop, Stejskal and Hudec, 2019):

$$
I N N=\beta_{0}+\sum_{i=1}^{m} \beta_{i} X_{i}+\varepsilon
$$

where INN is an innovation output, $x_{i}$ is a vector of variable $\mathrm{s}$ that influences the innovation output, $\beta_{i}$ is a vector of corresponding coefficients and $\varepsilon$ is an error term.

Data quality testing was performed and the data were tested for collinearity by using the Spearman correlation coefficient (rho). Results showed that the correlation between variables is significantly different from zero (rho ranges between $-1 \leq$ rho $\leq 1$ ). Variance Inflation Factor (VIF) were also used to test 
independent variables for collinearity (all models had VIF $<5$, multicollinearity was not found).

\section{RESULTS}

Following part contains results of our research models, while Tables 3 and 4 include analyses of determinants influencing overall, product and process innovations in selected CEE countries. Results of randomly selected 400 firms across countries are shown in Table 5.

Table 3 shows that firms' overall innovation activities within the Czech Republic are influenced by sales on the national market, training for innovative activities, internal or contractual activities for the launch of a new or improved products or services, and internal or contractual activities related to product design. On the other hand, in the Slovak Republic, significant determinants are participation in the firm group, and sales to other countries. Significant positive determinants of product innovation activities in the Czech Republic are sales to other countries, internal R\&D, external R\&D, market introduction of innovations, and design. Surprisingly, the acquisition of machinery, equipment, software, and buildings has significant negative impact on firms' product innovation. In the Slovak Republic, significant positive determinants are participation in the firm group, internal $\mathrm{R} \& \mathrm{D}$, obtaining existing knowledge from other companies or organizations, and market introduction of innovations.

In the analysis of significant determinants of process innovation activities in the Czech Republic, we found a positive impact of participation in the firm group, acquisition of machinery, equipment, software and buildings, training, training for innovative activities, and public financial support from the EU. On the other hand, sales on the national market have a significant negative impact. Significant positive determinants of process innovation activities are participation in the firm group and acquisition of machinery, equipment, software and buildings in the Slovak Republic. On the other hand, public financial support from the government has a significant negative influence. 
Table 3 - Influence of Innovation Determinants on Firm's Innovation Activities in the Czech Republic And nn the Slovak Republic

\begin{tabular}{|c|c|c|c|c|c|c|}
\hline \multirow[t]{3}{*}{ Determinant } & \multicolumn{3}{|c|}{ Czech Republic } & \multicolumn{3}{|c|}{ Slovak Republic } \\
\hline & $\begin{array}{l}\text { Overall } \\
\text { innovation } \\
\text { activities } \\
\text { p-value }= \\
0.0000 \\
\text { Success } \\
\text { rate: } 75.0 \%\end{array}$ & $\begin{array}{l}\text { Product } \\
\text { innovation } \\
\text { activities } \\
\text { p-value }= \\
0.0000 \\
\text { Success } \\
\text { rate: } 78.1 \%\end{array}$ & $\begin{array}{l}\text { Process } \\
\text { innovation } \\
\text { activities } \\
\text { p-value }= \\
0.0000 \\
\text { Success } \\
\text { rate: } 71.2 \%\end{array}$ & $\begin{array}{l}\text { Overall } \\
\text { innovation } \\
\text { activities } \\
\text { p-value }= \\
0.0054 \\
\text { Success } \\
\text { rate: } 72.6 \%\end{array}$ & $\begin{array}{l}\text { Product } \\
\text { innovation } \\
\text { activities } \\
\text { p-value }= \\
0.0000 \\
\text { Success } \\
\text { rate: } 82.3 \%\end{array}$ & $\begin{array}{l}\text { Process } \\
\text { innovation } \\
\text { activities } \\
\text { p-value }= \\
0.0001 \\
\text { Success } \\
\text { rate: } 70.9 \%\end{array}$ \\
\hline & $\mathrm{p}$-value $\beta_{\mathrm{i}}$ & $\mathrm{p}$-value $\beta_{\mathrm{i}}$ & $\mathrm{p}$-value $\beta_{\mathrm{i}}$ & p-value $\beta_{\mathrm{i}}$ & $\mathrm{p}$-value $\beta_{\mathrm{i}}$ & $\mathrm{p}$-value $\beta_{\mathrm{i}}$ \\
\hline Intercept & $\begin{array}{c}0.0000 * * * \\
(1.5565)\end{array}$ & $\begin{array}{c}0.3015 \\
(0.2020)\end{array}$ & $\begin{array}{c}0.0024 * * * \\
(-0.5385)\end{array}$ & $\begin{array}{c}0.0106 * * \\
(2.2832)\end{array}$ & $\begin{array}{c}0.2068 \\
(0.6530)\end{array}$ & $\begin{array}{c}0.5030 \\
(-0.2681)\end{array}$ \\
\hline GP & $\begin{array}{c}0.3774 \\
(0.1604)\end{array}$ & $\begin{array}{c}0.2432 \\
(-0.1372)\end{array}$ & $\begin{array}{c}0.0016^{* * * *} \\
(0.3217)\end{array}$ & $\begin{array}{l}0.0972 * \\
(0.6987)\end{array}$ & $\begin{array}{c}0.0206 * * \\
(0.6422)\end{array}$ & $\begin{array}{c}0.0527 * * \\
(0.4201)\end{array}$ \\
\hline MARLOC & $\begin{array}{c}0.3419 \\
(0.1718)\end{array}$ & $\begin{array}{c}0.5592 \\
(-0.0708)\end{array}$ & $\begin{array}{c}0.5284 \\
(0.0676)\end{array}$ & $\begin{array}{c}0.2554 \\
(0.4566)\end{array}$ & $\begin{array}{l}0.0822 * \\
(0.4854)\end{array}$ & $\begin{array}{c}0.2075 \\
(-0.2924)\end{array}$ \\
\hline MARNAT & $\begin{array}{c}0.0961 * \\
(-0.3994)\end{array}$ & $\begin{array}{c}0.3257 \\
(-0.1405)\end{array}$ & $\begin{array}{l}0.0427 * * \\
(-0.2918)\end{array}$ & $\begin{array}{c}0.4393 \\
(-0.4597)\end{array}$ & $\begin{array}{c}0.1858 \\
(-0.5222)\end{array}$ & $\begin{array}{c}0.2515 \\
(0.3548)\end{array}$ \\
\hline MAREUR & $\begin{array}{c}0.2745 \\
(0.2198)\end{array}$ & $\begin{array}{c}0.9551 \\
(-0.0007)\end{array}$ & $\begin{array}{c}0.7424 \\
(0.0404)\end{array}$ & $\begin{array}{c}0.1653 \\
(-0.6601)\end{array}$ & $\begin{array}{c}0.4391 \\
(-0.2463)\end{array}$ & $\begin{array}{c}0.2157 \\
(-0.3339)\end{array}$ \\
\hline MAROTH & $\begin{array}{c}0.3091 \\
(0.2065)\end{array}$ & $\begin{array}{c}0.0077 * * * \\
(0.3255)\end{array}$ & $\begin{array}{c}0.3084 \\
(0.1116)\end{array}$ & $\begin{array}{l}0.0889 * \\
(0.7669)\end{array}$ & $\begin{array}{l}0.0792 * \\
(0.5186)\end{array}$ & $\begin{array}{c}0.2208 \\
(0.2799)\end{array}$ \\
\hline RRDIN & $\begin{array}{c}0.8585 \\
(0.0342)\end{array}$ & $\begin{array}{c}0.0000 * * * \\
(0.7704)\end{array}$ & $\begin{array}{c}0.4930 \\
(-0.0747)\end{array}$ & $\begin{array}{c}0.2123 \\
(0.5292)\end{array}$ & $\begin{array}{c}0.0160 * * \\
(0.7073)\end{array}$ & $\begin{array}{c}0.9747 \\
(-0.0073)\end{array}$ \\
\hline RRDEX & $\begin{array}{c}0.1228 \\
(0.3745)\end{array}$ & $\begin{array}{c}0.0054 * * * \\
(0.4142)\end{array}$ & $\begin{array}{l}0.0783 * \\
(0.2076)\end{array}$ & $\begin{array}{c}0.7863 \\
(0.1882)\end{array}$ & $\begin{array}{c}0.9156 \\
(0.0469)\end{array}$ & $\begin{array}{c}0.9637 \\
(0.0139)\end{array}$ \\
\hline RMAC & $\begin{array}{c}0.5272 \\
(0.1202)\end{array}$ & $\begin{array}{c}0.0021 * * * \\
(-0.3983)\end{array}$ & $\begin{array}{c}0.0000 * * * \\
(0.9754)\end{array}$ & $\begin{array}{c}0.2945 \\
(-0.4743)\end{array}$ & $\begin{array}{c}0.8846 \\
(-0.0429)\end{array}$ & $\begin{array}{c}0.0015 * * * \\
(0.7303)\end{array}$ \\
\hline ROEK & $\begin{array}{c}0.1214 \\
(0.5340)\end{array}$ & $\begin{array}{l}0.0590 * \\
(0.3480)\end{array}$ & $\begin{array}{c}0.2486 \\
(0.1660)\end{array}$ & $\begin{array}{c}0.1527 \\
(0.9667)\end{array}$ & $\begin{array}{c}0.0686 * * \\
(0.7060)\end{array}$ & $\begin{array}{c}0.8218 \\
(0.0610)\end{array}$ \\
\hline RTR & $\begin{array}{c}0.0372 * * \\
(0.4003)\end{array}$ & $\begin{array}{c}0.7748 \\
(-0.0341)\end{array}$ & $\begin{array}{c}0.0000 * * * \\
(0.4798)\end{array}$ & $\begin{array}{c}0.3670 \\
(-0.3534)\end{array}$ & $\begin{array}{c}0.5169 \\
(-0.1850)\end{array}$ & $\begin{array}{c}0.3695 \\
(0.2082)\end{array}$ \\
\hline RMAR & $\begin{array}{c}0.0000^{* * * *} \\
(1.3882)\end{array}$ & $\begin{array}{c}0.0000 * * * \\
(1.6176)\end{array}$ & $\begin{array}{c}0.9823 \\
(-0.0028)\end{array}$ & $\begin{array}{c}0.4274 \\
(0.4371)\end{array}$ & $\begin{array}{c}0.0045 * * * \\
(1.2395)\end{array}$ & $\begin{array}{c}0.2163 \\
(-0.3247)\end{array}$ \\
\hline RDSG & $\begin{array}{l}0.0780 * \\
(0.4688)\end{array}$ & $\begin{array}{c}0.0000 * * * \\
(0.9476)\end{array}$ & $\begin{array}{c}0.9296 \\
(0.0109)\end{array}$ & $\begin{array}{c}0.8933 \\
(0.0609)\end{array}$ & $\begin{array}{c}0.5648 \\
(0.2209)\end{array}$ & $\begin{array}{c}0.3559 \\
(-0.2448)\end{array}$ \\
\hline FUNLOC & $\begin{array}{c}0.1929 \\
(0.6275)\end{array}$ & $\begin{array}{c}0.6523 \\
(0.1112)\end{array}$ & $\begin{array}{c}0.8984 \\
(-0.0264)\end{array}$ & $\begin{array}{c}0.9999 \\
(23.1410)\end{array}$ & $\begin{array}{c}0.2477 \\
(1.2849)\end{array}$ & $\begin{array}{c}0.1416 \\
(1.5950)\end{array}$ \\
\hline FUNGMT & $\begin{array}{c}0.8909 \\
(0.0305) \\
\end{array}$ & $\begin{array}{c}0.7010 \\
(-0.0544)\end{array}$ & $\begin{array}{c}0.5998 \\
(0.0627) \\
\end{array}$ & $\begin{array}{c}0.4256 \\
(-0.5385) \\
\end{array}$ & $\begin{array}{c}0.6568 \\
(-0.2408)\end{array}$ & $\begin{array}{l}0.0223 * * \\
(-0.9805)\end{array}$ \\
\hline FUNEU & $\begin{array}{c}0.8434 \\
(0.0472)\end{array}$ & $\begin{array}{c}0.4910 \\
(0.1044)\end{array}$ & $\begin{array}{c}0.0002 * * * \\
(0.5040)\end{array}$ & $\begin{array}{c}0.4758 \\
(-0.4275)\end{array}$ & $\begin{array}{c}0.5813 \\
(-0.2503)\end{array}$ & $\begin{array}{c}0.9005 \\
(-0.0462)\end{array}$ \\
\hline
\end{tabular}

Legend: the table shows the results of p-values and $\beta_{\mathrm{i}}$ coefficients (in round brackets) for the models of logistic regression in the Czech Republic and Slovak Republic * significant at significance level P <0.1; $* *$ significant at significance level P $<0.05$; *** significant at significance level P $<0.01$. 
Table 4 shows that 4 determinants have a statistically significant effect on the firms' overall innovation activities in Lithuania. These are acquisition of machinery, equipment, software, and buildings; market introduction of innovations; public financial support from the government, and public financial support from the EU. In the case of Estonia, overall innovation activities are significantly influenced by following determinants: participation in the firm group, sales on the national market, public financial support from local and regional institutions, public financial support from the government, and public financial support from EU. Significant positive determinants of product innovation activities in Lithuania are internal $\mathrm{R} \& \mathrm{D}$, market introduction of innovations, and design. In Estonia, the significant positive impact has internal $\mathrm{R} \& \mathrm{D}$, market introduction of innovations, acquisition of machinery, equipment, software and buildings, sales to other countries, and design.

In the case of process innovation activities in Lithuania, we found out training, training for innovative activities, and acquisition of machinery, equipment, software and buildings as significant positive determinants. However, the design has a significant negative impact on process innovation activities. In Estonia only the acquisition of machinery, equipment, software and buildings plays a positive significant role.

Table 4 - Influence of Innovation Determinants on Firm's Innovation Activities in Lithuania and Estonia

\begin{tabular}{|c|c|c|c|c|c|c|}
\hline \multirow[t]{3}{*}{ Determinant } & \multicolumn{3}{|c|}{ Lithuania } & \multicolumn{3}{|c|}{ Estonia } \\
\hline & $\begin{array}{l}\text { Overall } \\
\text { innovation } \\
\text { activities } \\
\text { p-value }= \\
0.0002 \\
\text { Success } \\
\text { rate: } 67.2 \%\end{array}$ & $\begin{array}{l}\text { Product } \\
\text { innovation } \\
\text { activities } \\
\text { p-value = } \\
0.0000 \\
\text { Success } \\
\text { rate: } 72.3 \%\end{array}$ & $\begin{array}{l}\text { Process } \\
\text { innovation } \\
\text { activities } \\
\text { p-value }= \\
0.0000 \\
\text { Success } \\
\text { rate: } 74.8 \%\end{array}$ & $\begin{array}{l}\text { Overall } \\
\text { innovation } \\
\text { activities } \\
\text { p-value }= \\
0.0607 \\
\text { Success } \\
\text { rate: } 80 \%\end{array}$ & $\begin{array}{l}\text { Product } \\
\text { innovation } \\
\text { activities } \\
\text { p-value = } \\
0.0000 \\
\text { Success } \\
\text { rate: } 71.5 \%\end{array}$ & $\begin{array}{l}\text { Process } \\
\text { innovation } \\
\text { activities } \\
\text { p-value }= \\
0.0000 \\
\text { Success } \\
\text { rate: } 69.6 \%\end{array}$ \\
\hline & $\mathrm{p}$-value $\beta_{\mathrm{i}}$ & p-value $\beta_{\mathrm{i}}$ & p-value $\beta_{i}$ & $\mathrm{p}$-value $\beta_{\mathrm{i}}$ & $\mathrm{p}$-value $\beta_{\mathrm{i}}$ & $\mathrm{p}$-value $\beta_{\mathrm{i}}$ \\
\hline Intercept & $\begin{array}{c}0.0268 * * \\
(1.2063)\end{array}$ & $\begin{array}{c}0.8509 \\
(-0.0546)\end{array}$ & $\begin{array}{l}0.0619 * \\
(0.6565)\end{array}$ & $\begin{array}{c}0.2470 \\
(0.7605)\end{array}$ & $\begin{array}{l}0.0125 * * \\
(-1.2367)\end{array}$ & $\begin{array}{c}0.9594 \\
(-0.0236)\end{array}$ \\
\hline GP & $\begin{array}{c}0.7584 \\
(0.0973)\end{array}$ & $\begin{array}{c}0.4388 \\
(-0.1159)\end{array}$ & $\begin{array}{c}0.9411 \\
(-0.0136)\end{array}$ & $\begin{array}{l}0.0948 * \\
(0.5707)\end{array}$ & $\begin{array}{c}0.3005 \\
(0.2533)\end{array}$ & $\begin{array}{c}0.8442 \\
(0.0451)\end{array}$ \\
\hline MARLOC & $\begin{array}{c}0.6477 \\
(0.1935)\end{array}$ & $\begin{array}{c}0.6584 \\
(-0.0941)\end{array}$ & $\begin{array}{c}0.5382 \\
(-0.1720)\end{array}$ & $\begin{array}{c}0.8707 \\
(0.0581)\end{array}$ & $\begin{array}{c}0.1010 \\
(0.4119)\end{array}$ & $\begin{array}{c}0.6436 \\
(0.1079)\end{array}$ \\
\hline MARNAT & $\begin{array}{c}0.5236 \\
(0.2207)\end{array}$ & $\begin{array}{c}0.4545 \\
(-0.1314)\end{array}$ & $\begin{array}{c}0.8717 \\
(-0.0376)\end{array}$ & $\begin{array}{c}0.0297 * * \\
(0.8203)\end{array}$ & $\begin{array}{c}0.1722 \\
(0.3980)\end{array}$ & $\begin{array}{c}0.8222 \\
(0.0644)\end{array}$ \\
\hline MAREUR & $\begin{array}{c}0.4359 \\
(0.2823)\end{array}$ & $\begin{array}{c}0.8603 \\
(0.0317)\end{array}$ & $\begin{array}{c}0.7656 \\
(0.0694)\end{array}$ & $\begin{array}{c}0.5463 \\
(-0.2919)\end{array}$ & $\begin{array}{c}0.8379 \\
(0.0687)\end{array}$ & $\begin{array}{c}0.2944 \\
(-0.3468)\end{array}$ \\
\hline MAROTH & $\begin{array}{c}0.5155 \\
(0.2200)\end{array}$ & $\begin{array}{c}0.2166 \\
(0.1974)\end{array}$ & $\begin{array}{c}0.5913 \\
(-0.1083)\end{array}$ & $\begin{array}{c}0.9930 \\
(0.0031)\end{array}$ & $\begin{array}{c}0.0129 * * \\
(0.5930)\end{array}$ & $\begin{array}{c}0.2063 \\
(-0.2846)\end{array}$ \\
\hline RRDIN & $\begin{array}{c}0.8158 \\
(-0.0763)\end{array}$ & $\begin{array}{c}0.0003 * * * \\
(0.6314)\end{array}$ & $\begin{array}{c}0.7561 \\
(-0.0620)\end{array}$ & $\begin{array}{c}0.8229 \\
(0.0803)\end{array}$ & $\begin{array}{c}0.0313 * * \\
(0.5458)\end{array}$ & $\begin{array}{c}0.1494 \\
(-0.3560)\end{array}$ \\
\hline
\end{tabular}




\begin{tabular}{|c|c|c|c|c|c|c|}
\hline \multirow[t]{3}{*}{ Determinant } & \multicolumn{3}{|c|}{ Lithuania } & \multicolumn{3}{|c|}{ Estonia } \\
\hline & $\begin{array}{l}\text { Overall } \\
\text { innovation } \\
\text { activities } \\
\text { p-value }= \\
\text { 0.0002 } \\
\text { Success } \\
\text { rate: } 67.2 \%\end{array}$ & $\begin{array}{l}\text { Product } \\
\text { innovation } \\
\text { activities } \\
\text { p-value }= \\
0.0000 \\
\text { Success } \\
\text { rate: } 72.3 \%\end{array}$ & $\begin{array}{l}\text { Process } \\
\text { innovation } \\
\text { activities } \\
\text { p-value }= \\
0.0000 \\
\text { Success } \\
\text { rate: } 74.8 \%\end{array}$ & $\begin{array}{l}\text { Overall } \\
\text { innovation } \\
\text { activities } \\
\text { p-value }= \\
0.0607 \\
\text { Success } \\
\text { rate: } 80 \%\end{array}$ & $\begin{array}{l}\text { Product } \\
\text { innovation } \\
\text { activities } \\
\text { p-value }= \\
0.0000 \\
\text { Success } \\
\text { rate: } 71.5 \%\end{array}$ & $\begin{array}{l}\text { Process } \\
\text { innovation } \\
\text { activities } \\
\text { p-value }= \\
0.0000 \\
\text { Success } \\
\text { rate: } 69.6 \%\end{array}$ \\
\hline & $\mathrm{p}$-value $\beta_{\mathrm{i}}$ & $\mathrm{p}$-value $\beta_{\mathrm{i}}$ & $\mathrm{p}$-value $\beta_{\mathrm{i}}$ & $\mathrm{p}$-value $\beta_{\mathrm{i}}$ & $\mathrm{p}$-value $\beta_{\mathrm{i}}$ & $\mathrm{p}$-value $\beta_{\mathrm{i}}$ \\
\hline RRDEX & $\begin{array}{c}0.9290 \\
(-0.0376)\end{array}$ & $\begin{array}{c}0.3501 \\
(-0.2142)\end{array}$ & $\begin{array}{c}0.2192 \\
(0.3261)\end{array}$ & $\begin{array}{c}0.6056 \\
(-0.1853)\end{array}$ & $\begin{array}{c}0.7861 \\
(-0.0671)\end{array}$ & $\begin{array}{c}0.5968 \\
(-0.1230)\end{array}$ \\
\hline RMAC & $\begin{array}{c}0.0000 * * * \\
(1.3094)\end{array}$ & $\begin{array}{c}0.3219 \\
(-0.1675)\end{array}$ & $\begin{array}{c}0.0000 * * * \\
(1.3872)\end{array}$ & $\begin{array}{c}0.5113 \\
(0.2314)\end{array}$ & $\begin{array}{c}0.0055 * * * \\
(-0.7224)\end{array}$ & $\begin{array}{c}0.0000 * * * * \\
(1.0803)\end{array}$ \\
\hline ROEK & $\begin{array}{c}0.5057 \\
(-0.2624)\end{array}$ & $\begin{array}{c}0.3700 \\
(0.1872)\end{array}$ & $\begin{array}{c}0.2440 \\
(-0.2739)\end{array}$ & $\begin{array}{c}0.3160 \\
(0.4002)\end{array}$ & $\begin{array}{c}0.1333 \\
(-0.3935)\end{array}$ & $\begin{array}{c}0.3937 \\
(0.2056)\end{array}$ \\
\hline RTR & $\begin{array}{c}0.4726 \\
(0.2330)\end{array}$ & $\begin{array}{c}0.5451 \\
(-0.0957)\end{array}$ & $\begin{array}{c}0.0134 * * \\
(0.4932)\end{array}$ & $\begin{array}{c}0.2895 \\
(0.4103)\end{array}$ & $\begin{array}{c}0.2606 \\
(0.2861)\end{array}$ & $\begin{array}{c}0.1606 \\
(0.3339)\end{array}$ \\
\hline RMAR & $\begin{array}{c}0.0497 * * \\
(0.9780)\end{array}$ & $\begin{array}{c}0.0000 * * * \\
(1.2699)\end{array}$ & $\begin{array}{c}0.4675 \\
(0.1798)\end{array}$ & $\begin{array}{c}0.2067 \\
(0.5317)\end{array}$ & $\begin{array}{c}0.0000 * * * \\
(1.4767)\end{array}$ & $\begin{array}{c}0.2879 \\
(-0.2762)\end{array}$ \\
\hline RDSG & $\begin{array}{c}0.6333 \\
(-0.1953)\end{array}$ & $\begin{array}{c}0.0000 * * * \\
(0.9705)\end{array}$ & $\begin{array}{c}0.0034 * * * \\
(-0.6774)\end{array}$ & $\begin{array}{c}0.6217 \\
(0.1999)\end{array}$ & $\begin{array}{c}0.0005 * * * \\
(0.9386)\end{array}$ & $\begin{array}{c}0.2942 \\
(-0.2676)\end{array}$ \\
\hline FUNLOC & $\begin{array}{c}0.9351 \\
(0.0693)\end{array}$ & $\begin{array}{c}0.1306 \\
(-0.5910)\end{array}$ & $\begin{array}{c}0.2984 \\
(0.6941)\end{array}$ & $\begin{array}{l}0.0673 * \\
(1.7745)\end{array}$ & $\begin{array}{c}0.9667 \\
(-0.0285)\end{array}$ & $\begin{array}{c}0.1644 \\
(0.9115)\end{array}$ \\
\hline FUNGMT & $\begin{array}{l}0.0909 * \\
(0.9842)\end{array}$ & $\begin{array}{c}0.6563 \\
(-0.0906)\end{array}$ & $\begin{array}{c}0.1414 \\
(0.4193) \\
\end{array}$ & $\begin{array}{l}0.0487 * * \\
(-0.9666)\end{array}$ & $\begin{array}{c}0.5538 \\
(-0.2093)\end{array}$ & $\begin{array}{c}0.3289 \\
(-0.3140) \\
\end{array}$ \\
\hline FUNEU & $\begin{array}{c}0.0575^{*} \\
(-0.6077)\end{array}$ & $\begin{array}{c}0.1739 \\
(0.2304)\end{array}$ & $\begin{array}{c}0.1034 \\
(-0.3258)\end{array}$ & $\begin{array}{c}0.0685^{*} \\
(1.0688)\end{array}$ & $\begin{array}{c}0.1206 \\
(0.5116)\end{array}$ & $\begin{array}{c}0.5337 \\
(0.1824)\end{array}$ \\
\hline
\end{tabular}

Legend: the table shows the results of p-values and $\beta_{\mathrm{i}}$ coefficients (in round brackets) for the models of logistic regression in the Lithuania and Estonia; * significant at significance level $\mathrm{P}<0.1$; ** significant at significance level $\mathrm{P}<0.05$; *** significant at significance level $\mathrm{P}<0.01$.

Table 5 shows the influence of innovation determinants on the firm's innovation activities in randomly selected 400 firms within CEE countries. Significant positive determinants of overall innovation activities are participation in the firm group, acquisition of machinery, equipment, software and buildings, and market introduction of innovations. In the analysis of product innovation activities, a total of 5 determinants were identified as positive significant: sales on the national market, sales to other countries, internal $R \& D$, market introduction of innovations, and design.

In the case of process innovation activities, we found out that participation in the firm group, acquisition of machinery, equipment, software and buildings, and public financial support from the EU have a significant positive impact. Surprisingly, determinants like internal R\&D and design have a negative impact on innovation process activities. 
Table 5 - Influence of Determinants on Innovation Activities in Random Companies in All 4 Countries

\begin{tabular}{|c|c|c|c|}
\hline Determinant & $\begin{array}{l}\text { Overall innovation } \\
\text { activities } \\
\text { p-value }=0.0003 \\
\text { Success rate: } 74.6 \%\end{array}$ & $\begin{array}{l}\text { Product innovation } \\
\text { activities } \\
\text { p-value }=0.0000 \\
\text { Success rate: } 70.3 \%\end{array}$ & $\begin{array}{l}\text { Process innovation } \\
\text { activities } \\
\text { p-value }=0.0000 \\
\text { Success rate: } 70.4 \%\end{array}$ \\
\hline & $\mathrm{p}$-value $\beta_{\mathrm{i}}$ & $\mathrm{p}$-value $\beta_{\mathrm{i}}$ & $\mathrm{p}$-value $\beta_{\mathrm{i}}$ \\
\hline Intercept & $\begin{array}{c}0.0026 * * * \\
(1.0160)\end{array}$ & $\begin{array}{c}0.2207 \\
(-0.2720)\end{array}$ & $\begin{array}{c}0.9130 \\
(-0.0238)\end{array}$ \\
\hline GP & $\begin{array}{c}0.0081 * * * \\
(0.5662)\end{array}$ & $\begin{array}{c}0.7326 \\
(0.0433)\end{array}$ & $\begin{array}{c}0.0076 * * * \\
(0.3300)\end{array}$ \\
\hline MARLOC & $\begin{array}{l}0.0748 * \\
(0.3824)\end{array}$ & $\begin{array}{c}0.3672 \\
(0.1242)\end{array}$ & $\begin{array}{c}0.2542 \\
(0.1525)\end{array}$ \\
\hline MARNAT & $\begin{array}{c}0.1069 \\
(0.3810)\end{array}$ & $\begin{array}{c}0.0035 * * * \\
(0.4434)\end{array}$ & $\begin{array}{c}0.9497 \\
(-0.0101)\end{array}$ \\
\hline MAREUR & $\begin{array}{c}0.7209 \\
(-0.0882)\end{array}$ & $\begin{array}{c}0.3589 \\
(-0.1427)\end{array}$ & $\begin{array}{c}0.0704 * \\
(-0.2859)\end{array}$ \\
\hline MAROTH & $\begin{array}{l}0.0861 * \\
(0.3825)\end{array}$ & $\begin{array}{c}0.0014 * * * \\
(0.4238)\end{array}$ & $\begin{array}{c}0.1631 \\
(0.1782)\end{array}$ \\
\hline RRDIN & $\begin{array}{c}0.7425 \\
(0.0720)\end{array}$ & $\begin{array}{c}0.0025 * * * \\
(0.4006)\end{array}$ & $\begin{array}{l}0.0122 * * \\
(-0.3256)\end{array}$ \\
\hline RRDEX & $\begin{array}{c}0.4211 \\
(-0.2034)\end{array}$ & $\begin{array}{c}0.5783 \\
(-0.0875)\end{array}$ & $\begin{array}{c}0.4188 \\
(-0.1187)\end{array}$ \\
\hline RMAC & $\begin{array}{c}0.0059 * * * \\
(0.5821)\end{array}$ & $\begin{array}{c}0.2274 \\
(-0.1675)\end{array}$ & $\begin{array}{c}0.0000^{* * * *} \\
(0.9306)\end{array}$ \\
\hline ROEK & $\begin{array}{c}0.8700 \\
(0.0437)\end{array}$ & $\begin{array}{c}0.1535 \\
(-0.2216)\end{array}$ & $\begin{array}{c}0.3837 \\
(-0.1283)\end{array}$ \\
\hline RTR & $\begin{array}{c}0.9620 \\
(-0.0105)\end{array}$ & $\begin{array}{c}0.9046 \\
(0.0158)\end{array}$ & $\begin{array}{c}0.1909 \\
(0.1692)\end{array}$ \\
\hline RMAR & $\begin{array}{c}0.0141 * * \\
(0.7240)\end{array}$ & $\begin{array}{c}0.0000 * * * \\
(1.2016)\end{array}$ & $\begin{array}{c}0.9671 \\
(-0.0062)\end{array}$ \\
\hline RDSG & $\begin{array}{c}0.5194 \\
(0.1797)\end{array}$ & $\begin{array}{c}0.0000 * * * \\
(0.7985)\end{array}$ & $\begin{array}{l}0.0143 * * \\
(-0.3641)\end{array}$ \\
\hline FUNLOC & $\begin{array}{c}0.4214 \\
(0.4519)\end{array}$ & $\begin{array}{c}0.3266 \\
(-0.2958)\end{array}$ & $\begin{array}{c}0.2936 \\
(0.3571)\end{array}$ \\
\hline FUNGMT & $\begin{array}{c}0.6890 \\
(0.1195) \\
\end{array}$ & $\begin{array}{c}0.9273 \\
(0.0163) \\
\end{array}$ & $\begin{array}{c}0.3470 \\
(0.1621) \\
\end{array}$ \\
\hline FUNEU & $\begin{array}{c}0.9815 \\
(-0.0063)\end{array}$ & $\begin{array}{c}0.2569 \\
(0.1875)\end{array}$ & $\begin{array}{c}0.0251 * * \\
(0.3672)\end{array}$ \\
\hline
\end{tabular}

Legend: the table shows the results of $p$-values and $\beta_{i}$ coefficients (in parentheses) for the given models of logistic regression in random countries; * significant at significance level $\mathrm{P}<0.1$; ** significant at significance level $\mathrm{P}<0.05$; *** significant at significance level $\mathrm{P}<0.01$. 


\section{DISCUSSION AND IMPLICATIONS}

For product innovation activities, internal $R \& D$ was found to be a significant positive factor, both in individual countries and in the random selection of CEE countries. These results are consistent with the results of previous studies, see Kotkova Strríteská and Prokop (2020) and Odei, Stejskal and Prokop (2020). Surprisingly, in the case of internal R\&D, we found a significant negative effect of internal R\&D on firms' process innovation for the random selection of CEE countries. Moreover, externally provided R\&D was identified as significant only in the case of the Czech Republic. In the case of process innovation activities, the most significant positive determinant is the acquisition of modern machinery, equipment, software, and buildings, which was identified significant within individual countries and consequently within the random selection of CEE countries. Lewandowska, Szymura-Tyc and Gołębiowski (2016) proved this significance in a sample of Polish companies from the traditional industry tended to appear in high/medium-tech companies. The Czech Republic and the Slovak Republic, similarly to the random selection of companies from the CEE countries, positively benefit from participation in the firm group. For the Czech Republic and the selection of companies from the CEE countries, public financial support from the EU is important.

Firms' overall innovation activities were significantly influenced by the following determinants - marketing activities related to the introduction of new products and services on the market; acquisition of modern machines, equipment, buildings, and software, as well as determinants expressing the market, served in terms of geography. These results are in accordance with D'Attoma and Ieva (2020) who found out, in the case of German firms, that marketing activities at the aggregate level were not a significant determinant to innovation success. For the Baltic States (Lithuania and Estonia), public financial support is important. Lithuania tends to benefit from public financial support from the government nevertheless public financial support from the EU has a negative impact on overall innovation activities. Surprisingly, in Estonia, public financial support from the government has a significant negative impact on overall innovation activities. Similarly to Prokop, Stejskal and Hajek (2018), public funding from the government play a key role in the process of firms' innovation activities, while misdirected financial support can lead to rather negative effects.

Based on the result of these analyses, we propose some practical implications. Czech innovating firms should invest in employees' $\mathrm{R} \& \mathrm{D}$ trainings that could boost their innovation activities and absorptive capacity. It is specifically crucial because of the importance of internal R\&D in the Czech Republic. Moreover, Czech firms should pay attention to the market research and launch advertising, including markets outside the EU. In addition, firms should also focus on design activities. Slovak innovating firms should participate in firm groups that can make it easier for individual companies to access additional knowledge resources, share costs together and benefit from the goodwill of other companies. 
Moreover, Slovak firms should primarily focus on internal R\&D, also supported by acquisition of external intangible as well as tangible assets.

In the case of Lithuania, market research and launch advertising, acquisition of advanced machinery, equipment, software and buildings are highly recommended. Similarly to other countries, support of internal R\&D and design are crucial for firms' innovation activities. These activities could be supported by trainings of employees. On the other hand, Estonian firms should focus primarily on the national markets. Moreover, public policy makers need to make provision of public funds more efficient because financial support from the government had a negative significant impact on firms' innovation activities. We propose following steps - matching the interests of individual (cooperating) actors, reducing the bureaucratic burden on companies, and greater control over the funds provided.

In general, from the results that we reached from the random selected datasets, we propose following implications. Firms should focus on activities for the market introduction of new or significantly improved goods or services, including market research and launch advertising. Moreover, we propose networking of firms and inter-firm cooperation activities. It is due to the fact that firms' participation in the firms' groups is significant. Moreover, we propose firms' cooperation with universities, as the generators of new knowledge. This kind of cooperation is also usually supported by public funds so it could provide additional funds for firms. Moreover, firms' cooperation could speed up the creation of knowledge spillovers as well as help to support firms' absorptive capacity that is also crucial in the process of internal $R \& D$ that is one of the key activities within CEE countries. In addition, creation of networks between firms could help to build external social capital that could subsequently help firms to avoid above-mentioned not-invented-here syndrome.

\section{CONCLUSION}

Finding proper determinants of firms' innovation activities was proved as a crucial task for firms, scholars and policy makers. However, as we have shown in this study, even after finding suitable determinants (for example, based on an extensive research on this topic), firms are not able to achieve innovative outputs, specifically within CEE countries. This is due, among other things, to several factors such as different conditions in individual countries, different innovation policies at the national as well as company level, managerial approach (aversion) to risk, mistrust between the various actors, and many others. A typical example is the impact of internal $\mathrm{R} \& \mathrm{D}$ on firm innovations. While in the case of product innovations we found a significant positive impact, in the case of process innovations the impact was negative. On the other hand, it creates number of challenges for the future research. It is necessary to focus on and deeply analyze the role of firm internal R\&D, absorptive capacity of firms within CEE countries and building of firm social capital. This study contains also some limitations. 
Primarily, analyzes were performed on outdated data. On the other hand, this fact provides us with basic results, which we can use in the following analyzes. Furthermore, we see as a possible limitation of this research in the fact that we did not make a comparison with countries from Western Europe. That is why we are also planning larger studies across European countries.

\section{ACKNOWLEDGEMENTS}

This work was supported by the Student Grant Competition of University of Pardubice SGS_2020_014.

\section{REFERENCES}

Arundel, A., 2017. Rethinking the effect of risk aversion on the benefits of service innovations in public administration agencies. Research Policy, [e-journal] 46(5), pp.900-910. DOI: 10.1016/j.respol.2017.03.009.

Asim, Z. and Sorooshian, S., 2019. Exploring the Role of Knowledge, Innovation and Technology Management (KNIT) Capabilities that Influence Research and Development. Journal of Open Innovation: Technology, Market, and Complexity, [e-journal] 5(2), 21p. DOI: 10.3390/joitmc5020021.

Asimakopoulos, G., Revilla, A.J. and Slavova, K., 2020. External knowledge sourcing and firm innovation efficiency. British Journal of Management, [e-journal] 31(1), pp.123-140. DOI: 10.1111/1467-8551.12367.

Bacon, E., Williams, M.D. and Davies, G., 2020. Coopetition in innovation ecosystems: A comparative analysis of knowledge transfer configurations. Journal of Business Research, [e-journal] 115, pp.307-316. DOI: 10.1016/j.jbusres.2019.11.005.

Barcelo-Valenzuela, M., Carrillo-Villafaña, P.S., Perez-Soltero, A. and SanchezSchmitz, G., 2016. A framework to acquire explicit knowledge stored on different versions of software. Information and Software Technology, [e-journal] 70, pp.40-48. DOI: 10.1016/j.infsof.2015.09.007.

Barkhordari, S., Fattahi, M. and Azimi, N.A., 2019. The impact of knowledgebased economy on growth performance: Evidence from MENA countries. Journal of the Knowledge Economy, [e-journal] 10(3), pp.1168-1182. DOI: $10.1007 / \mathrm{s} 13132-018-0522-4$.

Battistutti, O.C. and Bork, D., 2017. Tacit to explicit knowledge conversion. Cognitive processing, [e-journal] 18(4), pp.461-477. DOI: 10.1007/s10339-017-0825-6.

Bogers, M., Chesbrough, H. and Moedas, C., 2018. Open innovation: research, practices, and policies. California management review, [e-journal] 60(2), pp.516. DOI: $10.1177 / 0008125617745086$. 
Brinkley, I., 2006. Defining the knowledge economy. London: The Work Foundation.

Carayannis, E. and Grigoroudis, E., 2014. Linking innovation, productivity, and competitiveness: implications for policy and practice. The Journal of Technology Transfer, [e-journal] 39(2), pp.199-218. DOI: 10.1007/s10961-012-9295-2.

Che, T., Wu, Z., Wang, Y. and Yang, R., 2019. Impacts of knowledge sourcing on employee innovation: the moderating effect of information transparency. Journal of Knowledge Management, [e-journal] 23(2), pp.221-239. DOI: 10.1108/JKM-11-2017-0554.

Chergui, W., Zidat, S. and Marir, F., 2018. An approach to the acquisition of tacit knowledge based on an ontological model. Journal of King Saud UniversityComputer and Information Sciences, [e-journal] 32(7), pp.818-828. DOI: 10.1016/j.jksuci.2018.09.012.

Chesbrough, H.W., 2003. Open innovation: The new imperative for creating and profiting from technology. Harvard Business Press.

Chesbrough, H.W., 2017. The future of open innovation: The future of open innovation is more extensive, more collaborative, and more engaged with a wider variety of participants. Research-Technology Management, [e-journal] 60(1), pp.35-38. DOI: 10.1080/08956308.2017.1255054.

Chlebovský, V., Schüller, D. and Škapa, S., 2018. Are product innovationoriented firms prepared for effective product customization?. Scientific papers of the University of Pardubice. Series D, Faculty of Economics and Administration. 44/2018, pp.77-89.

D'Attoma, I. and Ieva, M., 2020. Determinants of technological innovation success and failure: Does marketing innovation matter?. Industrial Marketing Management, [e-journal] 91, pp.64-81. DOI: 10.1016/j.indmarman.2020.08.015.

Divisekera, S. and Nguyen, V.K., 2018. Determinants of innovation in tourism evidence from Australia. Tourism Management, [e-journal] 67, pp.157-167. DOI: 10.1016/j.tourman.2018.01.010.

Dries, L., Pascucci, S., Török, Á. and Tóth, J., 2014. Keeping your secrets public? Open versus closed innovation processes in the Hungarian wine sector. International Food and Agribusiness Management Review, [e-journal] 17(1030-2016-82970), pp.147-162. DOI: 10.22004/ag.econ.163358.

Dziallas, M. and Blind, K., 2019. Innovation indicators throughout the innovation process: An extensive literature analysis. Technovation, [e-journal] 80, pp.3-29. DOI: 10.1016/j.technovation.2018.05.005.

Forsman, H., 2011. Innovation capacity and innovation development in small enterprises. A comparison between the manufacturing and service sectors. Research policy, [e-journal] 40(5), pp.739-750. DOI: 10.1016/j.respol.2011.02.003. 
Goffin, K. and Koners, U., 2011. Tacit knowledge, lessons learnt, and new product development. Journal of Product Innovation Management, [e-journal] 28(2), pp.300-318. DOI: 10.1111/j.1540-5885.2010.00798.x.

Hau, Y.S., Kim, B., Lee, H. and Kim, Y.G., 2013. The effects of individual motivations and social capital on employees' tacit and explicit knowledge sharing intentions. International Journal of Information Management, [e-journal] 33(2), pp.356-366. DOI: 10.1016/j.ijinfomgt.2012.10.009.

Hudec, O., 2015. Visegrad countries and regions: Innovation performance and efficiency. Quality Innovation Prosperity, [e-journal] 19(2), pp.55-72. DOI: 10.12776/qip.v19i2.593.

Ili, S., Albers, A. and Miller, S., 2010. Open innovation in the automotive industry. $R \& d$ Management, [e-journal] 40(3), pp.246-255. DOI: 10.1111/j.14679310.2010.00595.x.

Ivanova-Gongne, M., Koporcic, N., Dziubaniuk, O. and Mandják, T., 2018. Collecting rich qualitative data on business relationships and networks in CEE countries: Challenges and plausible solutions. Industrial Marketing Management, [e-journal] 70, pp.193-204. 10.1016/j.indmarman.2017.07.007.

Janger, J., Schubert, T., Andries, P., Rammer, C. and Hoskens, M., 2017. The EU 2020 innovation indicator: A step forward in measuring innovation outputs and outcomes?. Research Policy, [e-journal] 46(1), pp.30-42. DOI: 10.1016/j.respol.2016.10.001.

Juknevičienè, V., 2017. Regional absorptive capacity and regional disparities in Lithuania: linkages, evidences and insights. Scientific papers of the University of Pardubice. Series D, Faculty of Economics and Administration, 40/2017, pp.7182.

Jurajda, Š., Kozubek, S., Münich, D. and Škoda, S., 2017. Scientific publication performance in post-communist countries: still lagging far behind. Scientometrics, [e-journal] 112(1), pp.315-328. DOI: 10.1007/s11192017-2389-8.

Kathoefer, D.G. and Leker, J., 2012. Knowledge transfer in academia: an exploratory study on the Not-Invented-Here Syndrome. The Journal of technology transfer, [e-journal] 37(5), pp.658-675. DOI: 10.1007/s10961-0109204-5.

Kotkova Stř́teská, M. and Prokop, V., 2020. Dynamic Innovation Strategy Model in Practice of Innovation Leaders and Followers in CEE Countries-A Prerequisite for Building Innovative Ecosystems. Sustainability, [e-journal] 12(9), 3918. DOI: 10.3390/su12093918. 
Kraftova, I. and Kraft, J., 2018. The Relationship between Pro-Innovation Factors and the Performance of the European Union Member States and their Regions. Inžinerine Ekonomika/Engineering Economics, [e-journal] 29(4), pp.424-433. DOI: 10.5755/j01.ee.29.4.19703.

Lavčák, M., Hudec, O. and Sinčáková, Ž., 2019. Local and Institutional Factors of Start-Up Ecosystems: Common and Inherited Attributes. Journal of the Knowledge Economy, [e-journal] 10(4), pp.1765-1783. DOI: 10.1007/s13132019-00598-0.

Lewandowska, M.S., Szymura-Tyc, M. and Gołębiowski, T., 2016. Innovation complementarity, cooperation partners, and new product export: Evidence from Poland. Journal of Business Research, [e-journal] 69(9), pp.3673-3681. DOI: 10.1016/j.jbusres.2016.03.028.

Li, Y., Tarafdar, M. and Rao, S.S., 2012. Collaborative knowledge management practices. International Journal of Operations \& Production Management, [e-journal] 32(4), pp.398-422. DOI: 10.1108/01443571211223077.

Liu, W. and Atuahene-Gima, K., 2018. Enhancing product innovation performance in a dysfunctional competitive environment: The roles of competitive strategies and market-based assets. Industrial Marketing Management, [e-journal] 73, pp.7-20. DOI: 10.1016/j.indmarman.2018.01.006.

Lukovics, M., Flipse, S.M., Udvari, B. and Fisher, E., 2017. Responsible research and innovation in contrasting innovation environments: Socio-Technical Integration Research in Hungary and the Netherlands. Technology in Society, [e-journal] 51, pp.172-182. DOI: 10.1016/j.techsoc.2017.09.003.

MacVaugh, J. and Schiavone, F., 2010. Limits to the diffusion of innovation. European journal of innovation management, [e-journal] 13(2), pp.197-221. DOI: 10.1108/14601061011040258.

Mahdi, O.R., Nassar, I.A. and Almsafir, M.K., 2019. Knowledge management processes and sustainable competitive advantage: An empirical examination in private universities. Journal of Business Research, [e-journal] 94, pp.320-334. DOI: 10.1016/j.jbusres.2018.02.013.

Manzini, R., Lazzarotti, V. and Pellegrini, L., 2017. How to remain as closed as possible in the open innovation era: the case of Lindt \& Sprüngli. Long range planning, [e-journal] 50(2), pp.260-281. DOI: 10.1016/j.lrp.2015.12.011.

Minárik, P., Vokoun, M. and Stellner, F., 2018. Innovative activity and business cycle: Austria in the 19th and 20th century. Economics and Management. E\&M Economics and Management, [e-journal] 21(2), pp.53-68. DOI: 10.15240/tul/001/2018-2-004.

Mokyr, J., 2002. The gifts of Athena: Historical origins of the knowledge economy. Princeton: Princeton University Press. 
Momeni, F., Elahi, N. and Najafi, S.M.S., 2017. Appropriate theoretical framework for understanding and analyzing economic issues in knowledge-based economy. Journal of the knowledge economy, [e-journal] 8(3), pp.957-976. DOI: 10.1007/s13132-015-0307-y.

Nielsen, B.B., 2010. Strategic fit, contractual, and procedural governance in alliances. Journal of Business Research, [e-journal] 63(7), pp.682-689. DOI: 10.1016/j.jbusres.2009.05.001.

Nonaka, I. and Takeuchi, H., 1995. The knowledge-creating company: How Japanese companies create the dynamics of innovation. Oxford: Oxford university press.

Odei, S.A., Stejskal, J. and Prokop, V., 2020. Revisiting the Factors Driving Firms' Innovation Performances: The Case of Visegrad Countries. Journal of the Knowledge Economy, pp.1-14. DOI: 10.1007/s13132-020-00669-7.

Park, S.O., 2001. Regional innovation strategies in the knowledge-based economy. GeoJournal, [e-journal] 53(1), pp.29-38. DOI: 10.1023/A:1015814611617.

Prokop, V. and Stejskal, J., 2019a. Different influence of cooperation and public funding on innovation activities within German industries. Journal of Business Economics and Management, [e-journal] 20(2), pp.384-397. DOI: 10.3846/jbem.2019.9620.

Prokop, V. and Stejskal, J., 2019b. Determinants of innovation activities and SME absorption-Case study of Germany. Scientific papers of the University of Pardubice. Series D, Faculty of Economics and Administration, 46/2019, pp.134146.

Prokop, V., Stejskal, J. and Hudec, O., 2019. Collaboration for innovation in small CEE countries. E+M Ekonomie a Management, [e-journal] 22(1), pp.130144. DOI: 10.15240/tul/001/2019-1-009.

Prokop, V., Stejskal, J., and Hajek, P., 2018. The influence of financial sourcing and collaboration on innovative company performance: A comparison of Czech, Slovak, Estonian, Lithuanian, Romanian, Croatian, Slovenian, and Hungarian case studies. In: J. Stejskal, P. Hajek and O. Hudec, eds. 2018. Knowledge Spillovers in Regional Innovation Systems (pp. 219-252). Springer, Cham.

Rohrbeck, R. and Gemünden, H.G., 2011. Corporate foresight: Its three roles in enhancing the innovation capacity of a firm. Technological Forecasting and Social Change, [e-journal] 78(2), pp.231-243. DOI: 10.1016/j.techfore.2010.06.019.

Stejskal, J., Mikušová Meričková, B., and Prokop, V., 2016. The cooperation between enterprises: significant part of the innovation process: a case study of the czech machinery industry. E+M Ekonomie a Management, [e-journal] 14(3), pp.110-122. DOI: 10.15240/tul/001/2016-3-008. 
Sun, Y., Liu, J. and Ding, Y., 2020. Analysis of the relationship between open innovation, knowledge management capability and dual innovation. Technology Analysis \& Strategic Management, [e-journal] 32(1), pp.15-28. DOI: 10.1080/09537325.2019.1632431.

Tchamyou, V.S., 2017. The role of knowledge economy in African business. Journal of the Knowledge Economy, [e-journal] 8(4), pp.1189-1228. DOI: 10.1007/s13132-016-0417-1.

Vasin, S.M., Gamidullaeva, L.A., Wise, N. and Korolev, K.Y., 2020. Knowledge exchange and the trust institution: A new look at the problem. Journal of the Knowledge Economy, [e-journal] 11(3), pp.1026-1042. DOI: 10.1007/s13132019-00588-2.

Wang, S., Fan, J., Zhao, D. and Wang, S., 2016. Regional innovation environment and innovation efficiency: the Chinese case. Technology Analysis \& Strategic Management, [e-journal] 28(4), pp.396-410. DOI: 10.1080/09537325.2015.1095291.

Žítek, V. and Klimova, V., 2016. Identification of Knowledge Bases: The Case of the Czech Republic. Engineering Economics, [e-journal] 27(5), pp.568-577. DOI: $10.5755 /$ j01.ee.27.5.14276.

Zona, F., Zattoni, A. and Minichilli, A., 2013. A contingency model of boards of directors and firm innovation: The moderating role of firm size. British Journal of Management, [e-journal] 24(3), pp.299-315. DOI: 10.1111/j.14678551.2011.00805.x.

\section{ABOUT AUTHORS}

Michael Vávra ${ }^{0000-0002-3879-7719}$ (M.V.) - Ph.D. Candidate in the field of public and regional economics, Faculty of Economics and Administraiton, University of Pardubice, Pardubice, Czech Republic, e-mail: michael.vavra@upce.cz.

Gregor Vohralík (G.V.) - Faculty of Economics and Administraiton, University of Pardubice, Pardubice, Czech Republic, e-mail: gregor.vohralik@student.upce.cz.

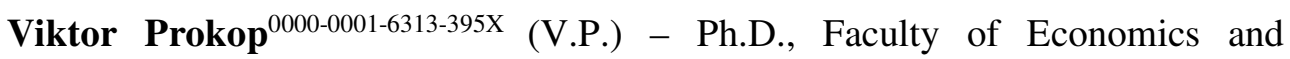
Administraiton, University of Pardubice, Pardubice, Czech Republic, e-mail: viktor.prokop@upce.cz.

Jan Stejskal ${ }^{0000-0003-3015-8274}$ (J.S.) - Prof., Faculty of Economics and Administration, University of Pardubice, Pardubice, Czech Republic, e-mail: jan.stejskal@upce.cz. 


\section{AUTHOR CONTRIBUTIONS}

Conceptualization, V.P. and G.V.; Methodology, G.V.; Formal analysis, V.P.; Original draft preparation, M.V.; Review and editing, J.S.; Visualization, M.V. and V.P.; Supervision, J.S.; Funding acquisition, V.P.

\section{CONFLICTS OF INTEREST}

The authors declare no conflict of interest. The funders had no role in the design of the study; in the collection, analyses, or interpretation of data; in the writing of the manuscript, or in the decision to publish the results.

(C) 2021 by the authors. Submitted for possible open access publication under the terms and conditions of the Creative Commons Attribution (CC-BY) license (http://creativecommons.org/licenses/by/4.0/). 